\title{
DETECTION OF Nosema spp. IN WORKER BEES OF DIFFERENT AGES DURING THE FLOW SEASON
}

\author{
Rajmund Sokól, Maria Michalczyk \\ Department of Parasitology and Invasive Diseases, \\ Faculty of Veterinary Medicine, University of Warmia and Mazury in Olsztyn, \\ Oczapowskiego 13, 10-718 Olsztyn, Poland \\ e-mail: maria.michalczyk@uwm.edu.pl
}

Received 14 January; accepted 10 November 2012

\section{$\mathrm{S} \mathrm{u} \mathrm{m} \mathrm{m} \mathrm{a} \mathrm{r} \mathrm{y}$}

The aim of this study was to identify which Nosema species infect those Apis mellifera worker bees performing different functions in the colony. Samples were taken from different places inside and outside the hive, in the honey flow season. In February 2010, winter hive debris from 30 colonies was analyzed, and based on the microsporidian species identified by multiplex PCR. The following bee colonies (none of which displayed clinical symptoms of the disease) were selected for further analyses to determine the occurrence of microsporidian parasites: 1) colony A/C infected with Nosema apis and N. ceranae (mixed infection), 2) colony A infected with N. apis, 3) colony $\mathrm{C}$ - infected with N. ceranae, and 4) colony $\mathrm{K}$ - the control, which was free of infection. Between April and August, 20 nurse bees from frames of open brood, and 20 forager bees returning to the hive from pollen-collecting trips were randomly selected from each colony at 30-day intervals. The results of the study indicate that the microsporidian species is determined not only by the type of worker bee (sampling site), but also by the period (month) of the sample collection. Our findings also suggest that regardless of the type of initial infection, bees infected by different microsporidian species and bees free from infection can coexist in colonies.

Keywords: Apis mellifera, Nosema ceranae, Nosema apis, PCR, seasonality.

\section{INTRODUCTION}

European honey bees (Apis mellifera) are affected by two microsporidian species of the genus Nosema spp. - the N. apis and the $N$. ceranae. Those single-celled parasitic organisms colonize the gastrointestinal tract of worker bees and drones. They are regarded as highly specialized fungi of the genus Microsporea (Fries, 2010). Worker bees are infected per os via food and water contaminated with parasitic spores (Chen et al., 2008; Webster et al., 2004). The main factors behind the spread of disease (nosemosis) in a bee colony are the weather conditions of every season of the year. Nosemosis caused by $N$. apis develops on a seasonal basis. In the spring, the intensity of infections caused by $N$. apis gradually increases as the bee colony develops. This pathogenic process is stabilized in the summer, and infection levels remain low. A repeated rise in parasite counts is noted in the fall, and it is often referred to as the "fall peak". Infections subside in the winter (Gajda, 2010; Higes et al., 2006). Recent research results obtained at European academic centers indicate that disease caused by the second microsporidian species, $N$. ceranae, poses a greater threat for bees of the genus $A$. mellifera than $N$. apis parasites. Bees affected by $N$. ceranae die quickly, usually outside the hive, without showing any prior clinical symptoms (Chen et al., 2009; Forsgren et al., 2010; Higes et al., 2007; Paxton et al., 2007). In contrast, with $N$. apis infections, the incidence of disease caused by $N$. ceranae remains leveled throughout the honey flow season (Klee et al., 2007; Martín-Hernández et al., 2007). 
The presence of Nosema spp. spores in bees is generally determined in water-based preparations of 10-20 crushed abdomen samples. A light microscope at $400 x$ magnification is used to view the abdomen samples. Nosema species are identified using PCR assays which determine the presence of the small subunit 16S rRNA sequence (Chen et al., 2008; Klee et al., 2007; Martín-Hernández et al., 2007; Topolska et al., 2007).

Studies conducted in recent years have focused on identifying microsporidian species of the genus Nosema spp. that affect honey bee colonies in different regions of the world (Klee et al., 2007; Pax to n et al., 2007; Tapaszti et al., 2007). The studies determined the phylogenetic origins of the microsporidian species (Fries, 2010; Huang et al., 2008; Williams et al., 2008) detecting their DNA in various body parts of bees (Chen et al., 2010), and analyzing microsporidian contamination of bee products (Higes et al., 2008; Meana et al., 2010; Botías et al., 2011).

The objective of this study was to determine the Nosema spp. species which during the honey flow season affect worker bees performing different functions in the colony. These worker bees had been infected by: $N$. apis or $N$. ceranae, $N$. apis in combination with $N$. ceranae, or were free of the disease during a spring examination of winter hive debris.

Due to Poland's climate, the detection of Nosema spores in winter hive debris determines further handling of bee colonies during the honey flow season.

\section{MATERIALS AND METHODS}

Before the first flight in the spring of 2010 , winter hive debris (bees found on the hive floor) was collected from 30 bee colonies kept in Dadant hives in the apiary at the University of Warmia and Mazury in Olsztyn, Poland. Based on the Nosema species identified in winter hive debris, the following bee colonies were selected to determine the presence of microsporidian parasites in the honey flow season: 1) colony $\mathrm{A} / \mathrm{C}$ infected with $N$. apis and
$N$. ceranae (mixed infection), 2) colony A infected with $N$. apis, 3) colony C infected with $N$. ceranae and 4) colony K - the control, which was free of infection. Between April and August, the following worker bees performing different functions in the hive were randomly selected from each colony at 30-day intervals, between 11 a.m. and noon:

1) 20 nurse bees, aged ca. 20 days, taking care of the brood, collected from frames of open brood inside the hive,

2) 20 forager bees, bringing pollen to the hive, collected with a handheld vacuum cleaner outside the hive.

Fifty worker bees, selected randomly from each debris sample, were examined for the presence of Nosema spp. Five analytical preparations were made by grinding 10 abdomens in a mortar with the addition of $10 \mathrm{ml} \mathrm{H}_{2} \mathrm{O}$. A drop of the resulting suspension was placed on a slide and covered with a cover slip. The preparation was studied under a light microscope at 400x magnification. The multiplex PCR method was used to identify the observed microsporidian species.

Nosema species were identified by the multiplex PCR method, as described below, in two replications for each sample ( 2 x 10 worker bees).

The suspension from the microscopic test was filtered and centrifuged (800g for 6 minutes). Genomic DNA was isolated using the Genomic Mini kit (A\&A Biotechnology, Gdynia, Poland) for DNA extraction. Purified DNA was stored in test-tubes at a temperature of $-20^{\circ} \mathrm{C}$ for further analysis. The multiplex PCR assay involved the amplification of the small subunit $16 \mathrm{~S}$ rRNA sequences of $N$. apis and $N$. ceranae. The following primer sequences were used: for $N$. apis - 321APIS FOR(5'-GGGGGCATGTCTTTGACGTA CTATGTA-3') and 321APIS REV (5'-GGG GGGCGTTTAAAATGTGAAA CA ACTATG-3'), amplifying products with the length of $321 \mathrm{bp}$, and for $N$. ceranae - 218 MITOC FOR (5'-CGGCG ACGATGTGATATGAAAATATTAA-3') and 218 MITOC REV (5'-CCCGGTCAT 
T C T C A A A C A A A A A A C C G - 3'), amplifying products with the length of 218 bp (OIE, 2008). The multiplex PCR analysis was carried out using the HotStarTaq Plus Polymerase (Qiagen) and the HotStarTaq Plus Master Mix Kit (Qiagen). The reaction mixture of $20 \mu \mathrm{l}$ comprised around $120 \mathrm{ng}$ isolated DNA

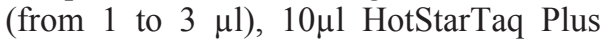
Master Mix 2x, $2 \mu 1$ CoralLoad Concentrate $10 \mathrm{x}$, and $0.1 \mu \mathrm{l}$ of each primer (with a final concentration of $0.5 \mu \mathrm{M}$ ), supplemented with RNase-Free Water to $20 \mu \mathrm{l}$. Every reaction involved three controls: two positive controls with the DNA of $N$. apis and $N$. ceranae (Centro Nosema Apicola Regional, Dirección Genera de la Producción Agropecuaria, Consejería de Agricultura, Junta de Comunidades de Castilla-La Mancha, Spain) and one negative control where DNA was replaced with water. The reaction was carried out in the Eppendorf Mastercycler thermocycler. The multiplex PCR commenced with initial denaturation for 5 minutes at $95^{\circ} \mathrm{C}$. The reaction mixture was then cycled 35 times consisting of the following steps: denaturation at $94^{\circ} \mathrm{C}$ for 45 seconds, primer annealing at $55^{\circ} \mathrm{C}$ for 45 seconds and extension at $72^{\circ} \mathrm{C}$ for 1 minute. The last reaction was followed by the final chain synthesis at $72^{\circ} \mathrm{C}$ for 10 minutes. The products of the multiplex PCR reaction were separated by electrophoresis in $2 \%$ agarose gel to visualize the resulting DNA fragments of Nosema spp. The size of the obtained products was evaluated by comparison with the GeneRuler ${ }_{\mathrm{TM}}$ $100 \mathrm{bp} 36$ Ladder Plus (Fermentas) molecular size marker. Electrophoresis results were archived using the GelDoc (Bio-Rad) gel documentation system (Michalczyk et al., 2011).

\section{RESULTS}

The results of analyses indicate that both nurse bees and forager bees of colony $\mathrm{A} / \mathrm{C}$, whose winter hive debris samples revealed the presence of a mixed infection, were also affected by a mixed infection in April and May. In June and July, the presence of only $N$. ceranae spores was detected in both analyzed bee types. The recurrence of a mixed infection was noted in August in both the nurse bees and the forager bees (Tab. 1).

In colony $\mathrm{A}$, which had been infected with $N$. apis, the presence of $N$. apis was noted in nurse bees in April. In May, July, and August, the examined bees were affected by a mixed infection (A/C). In June, no parasitic Nosema spp. were detected. Forager bees revealed the presence of $N$. apis spores in April and May. This group of bees was free of infection in June, whereas both Nosema species were observed in July and August.

Nurse bees of colony $\mathrm{C}$, which had been infected with $N$. ceranae, revealed the presence of $N$. ceranae spores in April. A mixed infection was observed in May, July, and August. The studied bees were free of infection in June. In April, May,

Table 1 .

Microsporidian species subject to the time of analysis and infection type

\begin{tabular}{||c|c|c|c|c|c|c||}
\hline \multirow{2}{*}{$\begin{array}{c}\text { Group } \\
\text { (colony) }\end{array}$} & \multirow{2}{*}{$\begin{array}{c}\text { Worker } \\
\text { bee type }\end{array}$} & \multicolumn{5}{|c||}{$\begin{array}{c}\text { Time of analysis } \\
\text { and infection type (Nosema spp.) }\end{array}$} \\
\cline { 3 - 8 } & & April & May & June & July & August \\
\hline \multirow{2}{*}{$\mathrm{AC}$} & nurse & $\mathrm{AC}$ & $\mathrm{AC}$ & $\mathrm{C}$ & $\mathrm{C}$ & $\mathrm{AC}$ \\
\cline { 2 - 7 } & forager & $\mathrm{AC}$ & $\mathrm{AC}$ & $\mathrm{C}$ & $\mathrm{C}$ & $\mathrm{AC}$ \\
\hline \multirow{2}{*}{$\mathrm{C}$} & nurse & $\mathrm{C}$ & $\mathrm{AC}$ & 0 & $\mathrm{AC}$ & $\mathrm{AC}$ \\
\cline { 2 - 8 } & forager & $\mathrm{AC}$ & $\mathrm{AC}$ & $\mathrm{AC}$ & $\mathrm{C}$ & $\mathrm{AC}$ \\
\hline \multirow{2}{*}{$\mathrm{A}$} & nurse & $\mathrm{A}$ & $\mathrm{AC}$ & 0 & $\mathrm{AC}$ & $\mathrm{AC}$ \\
\cline { 2 - 8 } & forager & $\mathrm{A}$ & $\mathrm{A}$ & 0 & $\mathrm{AC}$ & $\mathrm{AC}$ \\
\hline \multirow{2}{*}{$\mathrm{K}$} & nurse & 0 & 0 & 0 & $\mathrm{AC}$ & $\mathrm{AC}$ \\
\cline { 2 - 8 } & forager & 0 & 0 & 0 & $\mathrm{AC}$ & $\mathrm{AC}$ \\
\hline \hline
\end{tabular}


June, and August, forager bees were affected by a mixed infection $(\mathrm{A} / \mathrm{C})$, and the presence of $N$. ceranae spores was detected in this group in July.

Both types of worker bees from the control colony $(\mathrm{K})$, whose winter hive debris had not revealed the presence of parasitic spores, were free of infection in April, May, and June. A mixed infection $(\mathrm{A} / \mathrm{C})$ was noted in July and August in both nurse bees and forager bees (Tab. 1).

\section{DISCUSSION}

Martín-Hernández et al. (2006) reported that determination of Nosema ceranae is significantly influenced by the origin of the experimental material. They sampled bees at different hours and from different sites to demonstrate differences in spore counts between groups. According to the above authors, the highest rates of infection are observed in forager bees, regardless of the sampling time, and in forager and nurse bees which are collected around noon (Martín-Hernández et al., 2006). In the present study, we collected bees at the same time of the day to increase the reliability and comparability of results. As demonstrated by Botías et al. (2012), the detection of microsporidia is determined by sample size and sampling time (month, day), which supports our findings. The cited authors pointed also to a high degree of variation between samples collected randomly from different sites.

Our results show that bees collected randomly from winter hive debris in the spring may differ with respect to spore counts and the Nosema spp. species causing the infection. Despite the absence of clinical symptoms of nosemosis, the experiment revealed the presence of Nosema spp. spores in two types of worker bees in the analyzed groups. Nurse bees collected from the frames of open brood, which care for the brood and stay in the hive until the brood mature to become foragers, were first infected only by the Nosema species present in the hive. During the honey flow season, nurse bees were affected by both Nosema parasites, regardless of the initial infection. Forager bees, which leave the hive in search for nectar and pollen, may easily get reinfected by any microsporidian species. In the present study, the Nosema species detected in foragers was not always the same as the species found in nurse bees in a given month, e.g. colony C (April, June, July) and colony A (May). The results of our study suggest that the Nosema species is determined not only by the type of worker bee (sampling site resulting from the function they perform), but also the period (month) of sample collection. Martín-Hernández et al. (2012), who analyzed a total of 408 samples collected from 30 honeybee colonies, also observed seasonal variations in Nosema spp. infections. Nosema ceranae was found to be most frequent, present alone or with $N$. apis (mixed infection). Nosema apis was encountered most frequently from March to June, and from September to November, but only in $1.8 \%$ of forager bees. Nosema ceranae was detected in $38.63 \%$ of forager bees and $20.7 \%$ of nurse bees. Nurse bees were not infected with Nosema apis.

In a study by L'arrive (1963), samples from hive entrances contained twice as many spores as those from the brood nest. These findings indicate that sample collection site is an important consideration when examining bee colonies for Nosema spp. This is consistent with our findings. When the PCR method is used, both spore counts and Nosema species should be taken into account. El-Shemy and Pickard (1989) reported that the average count of $N$. apis spores per sample varied depending on the site of the bee sampling in the hive and the organ from which the spores were obtained. The highest spore counts were determined for flying bees; $80 \%$ of the spores were derived from the ventriculi and small intestines of bees, and $20 \%$ from the recta. According to the cited authors, the age of sampled bees was also an important consideration. Bees less than 8 days of age were free from spores. Mean spore counts increased linearly with age, reaching the highest level in bees older than 22 days. 
Smart and Sheppard (2012) studied $N$. ceranae and found that the intensity (mean number of spores per bee) and the prevalence (proportion of bees infected in a sample) of infection were determined by the age of the sampled bees (which were marked with paint). They demonstrated that the prevalence of Nosema in infected bees was positively correlated with the infection intensity in the sample.

The highly sensitive PCR technique, supports the identification of Nosema species of the genus Nosema spp. The pattern of infections caused by both Nosema species in nurse bees and foragers varied in different months of the study. In some months, the analyzed bee groups were free of infection. This probably means that bees infected by different Nosema species and bees free from infection can coexist in colonies. Interesting results were noted in August when a mixed infection was determined in all the analyzed colonies regardless of the sampling site. The above could be attributed to the parasites' mechanism of survival in the host's body.

Our results lay the ground for detailed studies investigating various classes of worker bees and individual (labeled) bees as well as the transmission routes of infection in bee colonies.

\section{ACKNOWLEDGMENTS}

This research project was funded by the National Science Center, grant number 5914/B/P01.2011/40.

\section{REFERENCES}

Botías C., Martín-Hernández R., Garrido-Bailón E., GonzálezPorto A., Martínez-Salvador A., Pilar De La Rúa, Meana A., Higes M. (2011) - The growing prevalence of Nosema ceranae in honey bees in Spain, an emerging problem for the last decade. Res. Vet. Sci., DOI: $10.1016 /$ j. rvc. 2011.08.002.
Botías C., Martín-Hernández R., Meana A., Higes M. (2012) - Critical aspects of the Nosema spp. diagnostic sampling in honey bee (Apis mellifera L.) colonies. Parasitol. Res., DOI 10.1007/ s00436-011-2760-2.

Chen Y., Evans J. D., Smith B. I., Pettis J. S. (2008) - Nosema ceranae is a long-present and wide-spread microsporidian infection of the European honey bee (Apis mellifera) in the United States. J. Invertebr. Pathol., 97: 186-188.

Chen Y.P., Evans J.D., Murphy C., Gutell R., Zuker M., GundensenRindal D., Pettis J. S. (2009) Morphological, molecular, and phylogenetic characterization of Nosema ceranae, a microsporidian parasite isolated from the European honey bee, Apis mellifera. J. Eukaryot. Microbiol., 56: 142-147.

Chen Y. P. Huang Z. Y. (2010.) - Nosema ceranae, a newly identified pathogen of Apis mellifera in the USA and Asia. Apidologie, 41: 364-374.

E1-Shemy A. A. M., Pickard R. S. (1989) - Nosema apis Zander infection levels in honeybees of known age. J. Apic. Res., 28: 101-106.

Fries I. (2010) - Nosema ceranae in European honey bees. J. Invertebr. Pathol. Suppl., 103: 73-79.

Forsgren E., Fries I. (2010) - Comarative virulence of Nosema ceranae and Nosema apis in individual European honey bees. Vet. Parasitol., 170: 212-217.

Gajda A. (2010) - Nosema ceranae in honeybee (Apis mellifera) colonies Życie Wet., 82: 140-143.

Higes M., Martín-Hernández R., Meana A. (2006) - Nosema ceranae, a new microsporidian parasite in honeybees in Europe. J. Invertebr. Pathol., 92: 93-95.

Higes M., García-Palencia P., Martín-Hernández R., Aránzazu M. (2007) - Experimental infection of Apis mellifera honeybees with Nosema ceranae (Microsporidia). J. Invertebr.Pathol., 94: 211217. 
Higes M., Martín-Hernández R., Garrido-Bailón E., GarcíaPalencia P., Meana A. (2008) - Detection of infective Nosema ceranae (Microsporidia) spores in corbicular pollen of forager honeybees. J. Invertebr.Pathol., 97:76-78.

Huang W. F., Bocquet M., Lee K. Ch., Sung I. H., Jiang J. H., Chen Y. P., Wang Ch. H. (2008) - The comparison of rDNA spacer regions of Nosema ceranae isolates from different hosts and locations. J. Invertebr.Pathol., 97: 9-13.

Klee J., Beasana A. M., Genersch E., Gisder S., Nanetti A., Tam D. Q., Chinh T. X., Puerta F., Ruz J. M., Kryger P., Message D., Hatjina F., Korpela S., Fries I., Paxton R. J. (2007) - Widespread dispersal of the microsporidian Nosema ceranae an emergent pathogen of the western honey bee, Apis mellifera. J. Invertebr. Pathol., 96: 1-10.

L'arrivee J. C. M. (1963) - The effects of sampling sites on Nosema determination. J. Insect. Pathol., 5: 349-355.

Martín-Hernández R., Higes M., Garrido M. Encarnación, GarcíaPalencia P., Meana A. (2006) - Influence of sapling in the detection of Nosema ceranae spores. In Proceedings of $2^{\text {nd }}$ European Conference of Apidology, Prague, 10-16 September, 2006; pp. 35.

Martín-Hernández R., Meana A., Prieto L., Salvador A. M., GarridoBailón E., Higes M. (2007) - Outcome of Colonization of Apis mellifera by Nosema ceranae. Appl. Environ. Microbiol., 73: 6331-6338.

Martín-Hernández R., Botías C., Garrido-Bailón E., MartínezSalvador A., Prieto L., Meana A., Higes M. (2012) - Microsporidia infecting Apis mellifera: coexistence or competition. Is Nosema ceranae replacing Nosema apis? Environ. Microbiol., DOI: 10.1111/j.14622920.2011.02645.x.
Meana A., Martín-Hernández R., Higes M. (2010) - The reliability of spore counts to diagnose Nosema ceranae infections in honey bees. J. Apic. Res., 49: 212-214.

Office International des Epizooties (OIE) 2008 - Manual of Standards for Diagnostic Test and Vaccines [online] http://www.oie.int/eng/ normes/manual/A_00123.htm.

Michalczyk M., Sokół R., SzczerbaTurek A., Bancerz-Kisiel A. (2011) A comparison of effectiveness of the microscopic and multiplex PCR method in identifying and discriminating the species of Nosema spp. spores in worker bees (Apis mellifera) from winter hive debris. Pol. J. Vet. Sci., 14: 385-391.

Paxton R., Klee J., Korpela S., Fries I. (2007) - Nosema ceranae has infected Apis mellifera in Europe since at least 1998 and may be more virulent than Nosema apis. Apidologie, 38: 558-565.

Smart M., Sheppard W. (2012) - Nosema ceranae in age cohorts of the western honey bee (Apis mellifera). J. Invertebr. Pathol., 109: 148-151.

Tapaszti Z., Forgách P., Kővágó C., Békési L., Bakonyi T., Rusvai M. (2009) - First detection and dominance of Nosema ceranae in Hungarian honeybee colonies. Acta Vet. Hung., 57: 383-388.

Topolska G., Kasprzak S. (2007) - First cases of Nosema ceranae infection in bees in Poland. Medycyna Wet. Suppl., 67: 1504-1506.

Webster T. C., Pomper K. W., Hunti G., Thacker E. M., Jones S. C. (2004) - Nosema apis infection in worker and queen Apis mellifera. Apidologie, 35: 49-54.

Williams G. R., Shafer A. B. A., Rogers R. E. L., Shutler D., Stewart D. T. (2008) - First detection of Nosema ceranae, a microsporidian parasite of European honey bees (Apis mellifera), in Canada and central USA. J. Invertebr. Pathol., 97: 189-192. 


\title{
WYKRYWANIE Nosema spp. U PSZCZÓŁ ROBOTNIC W RÓŻNYM WIEKU PODCZAS SEZONU PASIECZNEGO
}

\author{
Sokól R., Michalczyk M.
}

\section{S t r e s z c z e n i e}

Celem badań było ustalenie, który gatunek Nosema występuje u robotnic Apis mellifera pobieranych z różnych miejsc ula w sezonie pasiecznym. W lutym 2010 roku zbadano osypy zimowe pszczół z 30 rodzin pszczelich. W zależności od stwierdzonego gatunku sporowca (metodą multiplex PCR) dalszą ocenę występowania gatunku sporowców prowadzono w następujących grupach (rodzinach pszczelich bez objawów klinicznych choroby): AC - zainfekowana Nosema apis i Nosema ceranae (infekcja mieszana), A - zainfekowana $N$. apis, C - zainfekowana $N$. ceranae oraz grupa kontrolna $\mathrm{K}$, wolna od infekcji. Z każdej rodziny od kwietnia do sierpnia w odstępach 30 dniowych pobierano do badań losowo po 20 robotnic z dwóch miejsc: robotnice ulowe, bezpośrednio z plastrów z czerwiem otwartym oraz robotnice lotne - robotnice powracające do uli z pyłkiem. Wykazaliśmy, że nie tylko rodzaj robotnic (miejsce pobrania), ale i okres (miesiąc) pobrania prób do badań ma wpływ na rodzaj wykrywanego gatunku sporowca, a także, że niezależnie od rodzaju infekcji początkowej (w osypie zimowym) w rodzinach pszczelich mogą współistnieć osobniki zainfekowane różnymi gatunkami sporowca oraz wolne od infekcji.

Słowa kluczowe: Apis mellifera, Nosema ceranae, Nosema apis, PCR, sezonowość. 